\title{
PENGARUH TERAPI BERMAIN PUZZLE TERHADAP TINGKAT KECEMASAN AKIBAT HOSPITALISASI PADA ANAK USIA TODDLER
}

\author{
The Effect Of Playing Puzzle Therapy Towards Anxiety Level Due To The \\ Hospitalization Of Toddlers
}

\author{
Gede Sukadana $^{1}$, N.M.A Sukmandari ${ }^{2}$, K. Yogi Triana ${ }^{2}$ \\ ${ }^{1}$ Mahasiswa Program Studi S1 Keperawatan, STIKES Bina Usada Bali, Badung, Bali, Indonesia \\ ${ }^{2}$ Departemen Keperawatan Anak, STIKES Bina Usada Bali, Badung, Bali, Indonesia \\ Korespondensi : arisukmandarimd@gmail.com
}

\begin{abstract}
ABSTRAK
Anak adalah individu yang unik dengan kebutuhan yang sesuai dengan tumbuh kembangnya. Anak-anak memiliki daya tahan tubuh yang belum terbentuk dengan baik, sehingga sering sakit dan terpaksa dirawat di rumah sakit yang sering menyebabkan reaksi rawat inap. Reaksi anak-anak yang mengalami rawat inap termasuk kecemasan dan ketakutan. Salah satu teknik non-farmakologi yang dapat digunakan untuk mengatasi kecemasan anak adalah dengan memberikan terapi bermain puzzle. Tujuan dari penelitian ini adalah untuk mengetahui pengaruh terapi bermain puzzle terhadap tingkat kecemasan akibat penyakit rawat inap balita di Bangsal Durian RSUD Klungkung. Penelitian ini menggunakan desain preexperiment dengan rancangan penelitian one group pre-test post-test. Penentuan sampel menggunakan teknik insidental. Jumlah sampel 27 responden. Instrumen yang digunakan adalah angket tingkat kecemasan. Data dianalisis menggunakan uji statistik wilcoxon signed rank. Hasil pre-test didapatkan mayoritas anak mengalami kecemasan berat sebanyak 14 responden (15.9\%) dan didapatkan hasil post-test sebagian besar anak mengalami kecemasan ringan sebanyak 22 responden $(81,5 \%)$. Uji statistik diperoleh nilai $\mathrm{p}(0,000)<\alpha(0,05)$. Dapat disimpulkan bahwa terdapat pengaruh yang signifikan antara terapi bermain puzzle terhadap tingkat kecemasan akibat rawat inap balita. Anak yang mengalami rawat inap dapat diberikan terapi bermain puzzle mengurangi respons kecemasan yang mereka hadapi.
\end{abstract}

Kata Kunci: puzzle, kecemasan, balita

\begin{abstract}
Children are unique individuals with needs in accordance with growth and development. Children have an immune system that has not been formed properly, so they often get sick and have to be hospitalized which often causes a reaction to hospitalization. The reaction of children who experience hospitalization including anxiety and fear. One of the nonpharmacological techniques which can be used to overcome children's anxiety is by giving playing puzzle therapy. The purpose of this study was to determine the effect of playing puzzle therapy towards anxiety level due to the hospitalization of toddlers in the Durian Ward of Klungkung General Regional Hospital. This study uses pre experimental with one-group research design, with sample determination using an incidental sampling technique. The number of samples in this study was 27 respondents, while the instruments used were anxiety level questionnaires. Data were analyzed using the wilcoxon signed rank test. The results of the pre-test were obtained the majority of children experienced severe anxiety as many as 14 respondents $(15.9 \%)$ and the post-test results obtained most children experienced mild anxiety as many as 22 respondents (81.5\%). Based on the statistical test obtained p-value $(0,000)<\alpha$ $(0,05)$. It could be concluded that there was a significant effect of playing puzzle therapy towards anxiety level due to hospitalization of toddlers. Children who experienced hospitalization can be given playing puzzle therapy toreduce the anxiety response they face.
\end{abstract}

Keywords: puzzle, anxiaty, toddler 
Gede Sukadana, dkk: Pengaruh Terapi Bermain Puzzle Terhadap Tingkat Kecemasan Akibat Hospitalisasi Pada Anak Usia Toddler

\section{PENDAHULUAN}

Anak merupakan individu yang unik dengan kebutuhan sesuai dengan tahapan tumbuh kembang yang dilaluinya. Tumbuh kembang anak dimulai dari usia bayi, toddler, prasekolah, hingga remaja (Adriana, 2013). Anak yang berusia 1-3 tahun merupakan anak yang berada pada tahap usia toddler, pada masa ini anak cenderung rentan mengalami kondisi sakit karena sistem imun anak belum terbentuk secara sempurna. Apabila anak dalam kondisi sakit, maka anak harus menjalani perawatan di rumah sakit atau menjalani hospitalisasi (Wong, Hockenberry-Eaton, Wilson, L.Winkelstein, \& Schwartz, 2008). Hal ini akan membuat anak merasa ketakutan, merasa terancam, sepi, gelisah, bertemu dengan orang baru, lingkungan baru, dan cemas (Aizah \& Wati, 2014).

Anak yang mengalami cemas, secara otomatis tubuh akan mengeluarkan hormon kortisol sehingga mengakibatkan depresi atau menekan sistem imunologi, dan memperlambat proses penyembuhan (Aizah \& Wati, 2014). Menurut Basford \& Slevin (2010), kecemasan pada anak yang mengalami hospitalisasi disebabkan oleh beberapa faktor diantaranya cedera tubuh, nyeri, hilang kendali, serta anak mengalami perpisahan dengan lingkungan tempat tinggal dan teman bermain. Selain itu anak juga harus menyesuaikan diri dengan lingkungan baru di rumah (Basford \& Slevin, 2010).

Menurut WHO (2012), bahwa 3-10\% anak usia toddler mengalami kecemasan akibat hospitalisasi. Menurut Kementerian Kesehatan RI (2010) jumlah anak usia toddler di Indonesia cukup besar, yaitu sekitar 17,1 juta jiwa dari 87,9 juta anak. Data jumlah anak usia toddler di Kabupaten Klungkung yaitu lebih dari 13.000 anak, dengan angka kunjungan ke pelayanan kesehatan RSUD Klungkung sejumlah 4.675 kunjungan rawat jalan dan 1.246 rawat inap (Dikes Kabupaten Klungkung, 2015).

Anak yang mengalami kecemasan akibat hospitalisasi berdasarkan angka kunjungan ke pelayanan kesehatan RSUD Klungkung yaitu sebanyak $16,85 \%$ anak toddler mengalami kecemasan berat, $50,24 \%$ kecemasan sedang, dan 32,9\% kecemasan ringan (Dikes Kabupaten Klungkung, 2015). Berdasarkan Studi pendahuluan yang peneliti lakukan di Ruang Durian RSUD Kabupaten Klungkung pada tanggal 28-29 Agustus 2018, diperoleh data bahwa sebanyak 14 anak usia toddler mengalami kecemasan. Empat anak $(28,58 \%)$ mengalami kecemasan berat, tujuh anak $(50 \%)$ mengalami kecemasan sedang, dan tiga anak $(21,42 \%)$ mengalami kecemasan ringan. Dalam mengatasi kecemasan pada anak toddler di ruang Durian RSUD Kabupaten Klungkung, perawat hanya mengajak anak bermain atau jalan-jalan di luar kamar, karena belum ada terapi khusus yang diberikan di ruangan.

Menurut Wong et al. (2008), menyatakan bahwa salah satu terapi non farmakologi yang dapat diberikan pada anak usia toddler yang mengalami kecemasan akibat hospitalisasi yaitu mengalihkan dengan terapi bermain. Salah satu terapi bermain yang mudah diberikan pada anak yaitu diberikan aktivitas permainan dalam bentuk bermain puzzle (Alfiyanti, 2010). Selain mudah di dapat permainan puzzle bisa dilakukan pada ruang perawatan tanpa tempat khusus, serta tersedia beraneka ragam bentuk puzzle dan warna, sehingga anak tidak mudah bosan dalam bermain puzzle (Alfiyanti, 2010).

Manfaat dari bermain puzzle yaitu dapat melatih memori anak untuk mengingat kembali potongan gambar, anak juga dapat melatih keterampilan motorik halus, dan melatih koordinasi mata maupun tangan saat bermain (Alfiyanti, 2010). Berdasarkan latar belakang dan studi pendahuluan di atas, maka permasalahan ini penting untuk diteliti tentang pengaruh terapi bermain puzzle terhadap tingkat kecemasan akibat hospitalisasi pada anak usia toddler.

\section{TUJUAN PENELITIAN}

Adapun tujuan dari penelitian ini adalah menganalisis pengaruh terapi bermain puzzle terhadap tingkat kecemasan akibat hospitalisasi pada anak usia toddler. 
Gede Sukadana, dkk: Pengaruh Terapi Bermain Puzzle Terhadap Tingkat Kecemasan Akibat Hospitalisasi Pada Anak Usia Toddler

\section{METODE PENELITIAN}

Desain

Desain penelitian yang digunakan adalah preeksperimen dan dengan rancangan penelitian one group pretest dan posttest design yaitu penelitian yang mengungkapkan hubungan sebab akibat dengan cara melibatkan suatu kelompok subjek. Kelompok subjek diobservasi terlebih dahulu sebelum dan setelah dilakukan intervensi, kemudian diobservasi lagi setelah intervensi (Nursalam, 2013).

\section{Populasi dan Sampel}

Populasi yang terlibat dalam penelitian ini adalah seluruh anak usia 1-3 tahun yang menjalani rawat inap di RSUD Klungkung. Teknik pengambilan sampel menggunakan jenis non-probability sampling yaitu insidential sampling. Jumlah sampel 27 responden. Penentuan sampel ditentukan dengan melihat kriteria inklusi dan eksklusi. Kriteria inklusi dari penelitian ini yaitu: anak usia toddler yang dihospitalisasi di ruang Durian RSUD Kabupaten Klungkung; anak usia toddler yang mengalami kecemasan akibat hospitalisasi; orang tua anak yang bersedia anaknya dijadikan responden dalam penelitian. Kriteria eksklusi dalam penelitian ini yaitu: anak yang mengalami hambatan fisik seperti buta, tuli dan kecacatan pada ekstremitas atas; anak yang memiliki keterbelakangan mental; anak yang mengalami bedrest. Kriteria drop out pada penelitian ini yaitu: anak yang diperbolehkan pulang sebelum dilakukan postest; anak yang dipindahkan ke ruang perawatan intensif.

\section{Tempat dan Waktu Penelitian}

Penelitian dilaksanakan selama 4 minggu bertempat di Bangsa Durian RSUD Klungkung.

\section{Instrumen dan Prosedur Pengukuran}

Instrumen yang digunakan pada penelitian ini adalah kuesioner tingkat kecemasan akibat hospitalisasi berdasarkan respon fisiologis, psikologis, kognitf dan afektif. Pengukuran pre-test dilakukan setelah hari ke dua anak menjalani hospitalisasi. Pengukuran post-test dilakukan setelah diberikan terapi puzzle satu kali.

\section{Analisa Data}

Pada penelitian ini menggunakan analisa data univariat untuk mengetahui distribusi frekuensi masing-masing variabel. Uji bivariat pada penelitian ini menggunakan uji wilcoxon sign rank dengan tingkat kesalahan 5\%.

\section{Intervensi}

Intervensi pada penelitian berupa tindakan mengajak anak usia toddler bermain puzzel. Anak dengan usia satu tahun menggunakan puzzel 2-4 keping, anak dengan usia dua tahun menggunakan puzzel 5-6 keping, serta anak usia tiga tahun menggunakan puzzel 7-8 keping. Terapi dilaksanakan setiap pukul 16.00 WITA.

\section{HASIL PENELITIAN}

Temuan pada penelitian ini dilakukan uji statistik yang selanjutnya disajikan dalam bentuk tabel:

\section{Tabel 1}

Pengaruh Terapi Bermain Puzzle Terhadap Tingkat Kecemasan Akibat Hospitalisasi Pada Anak Usia Toddler $(\mathrm{n}=27)$

\begin{tabular}{cccccc}
\hline \multirow{3}{*}{ Variabel } & \multicolumn{3}{c}{ Tingkat Kecemasasn } & & \multirow{2}{*}{ P } \\
\cline { 2 - 4 } & Cemas & Cemas & Cemas & & \\
\cline { 2 - 4 } pre-test & 0 & 13 & 14 & & \\
& $(0 \%)$ & $(48 \%)$ & $(52 \%)$ & & \\
post-test & 22 & 5 & 0 & 0,001 & $-4,548$ \\
& $(81,5 \%)$ & $(18,5 \%)$ & $(0 \%)$ & & \\
\hline
\end{tabular}

Tabel 1 menunjukkan sebelum diberikan terapi bermain puzzle responden sebagian besar mengalami kecemasan berat sebanyak 14 anak (51,9\%). Setelah diberikan terapi bermain puzzle terjadi perubahan tingkat kecemasan responden yang sebagian besar mengalami kecemasan ringan sebanyak 22 anak (81,5\%). Hasil uji statistik wilcoxon sign rank diperoleh nilai $\mathrm{p}=0,001 \quad(\alpha<0,05)$. Berdasarkan hasil uji Wilcoxon maka terdapat pengaruh pemberian terapi bermain terhadap tingkat kecemasan anak usia toddler. Nilai $Z_{\text {hitung }}$ dari tingkat kecemasan anak usia toddler sebelum dan sesudah diberikan terapi bermain puzzle lebih besar $\left(\mathrm{Z}_{\text {hitung }}\right.$ 
Gede Sukadana, dkk: Pengaruh Terapi Bermain Puzzle Terhadap Tingkat Kecemasan Akibat Hospitalisasi Pada Anak Usia Toddler

$=4,548)$ dibandingkan dengan nilai $Z_{\text {tabel }}$ $\left(Z_{\text {tabel }}=1,96\right)$.

\section{PEMBAHASAN}

Tingkat kecemasan akibat hospitalisasi pada anak usia toddler di Ruang Durian RSUD Kabupaten Klungkung sebelum diberikan terapi bermain puzzle, menunjukkan responden sebagian besar mengalami kecemasan berat sebanyak 14 anak (51,9\%). Menurut Wahyuni, Suwani, \& Murtutik (2013), anak yang dihospitalisasi akan mengalami dampak kecemasan (kecemasan ringan, sedang dan berat). Dampak dari kecemasan yang tidak segera ditangani akan membuat anak melakukan penolakan terhadap tindakan perawatan dan pengobatan yang diberikan, sehingga berpengaruh terhadap lamanya hari rawat inap. Anak yang mengalami kecemasan akan mengalami kelelahan karena menangis terus, tidak mau berinteraksi dengan perawat, rewel, dan tidak kooperatif terhadap perawatan.

Tingkat Kecemasan Akibat Hospitalisasi Pada Anak Usia Toddler di Ruang Durian RSUD Kabupaten Klungkung setelah diberikan terapi bermain puzzle, menunjukan responden sebagian besar mengalami kecemasan ringan sebanyak 22 anak $(81,5 \%)$. Hal ini sesuai dengan pendapat dari Soebachman (2012)dengan terapi bermain puzzle anak dapat mengurangi kecemasanya atau setres selama hospitalisasi, melatih memori, mengasah keterampilan motorik halus anak dan melatih keterampilan sosial. Menurut Saputro \& Fazrin (2017), menciptakan suasana yang tenang dengan memberikan anak terapi bermain puzzle, maka secara tidak sadar anak dapat melupakan dan mengeluarkan masalah selama di hospitalisasi seperti rasa cemas, sedih, takut, tertekan, dan setres.

Uji statistik dalam penelitian ini dilakukan menggunakan uji wilcoxon sign rank untuk mengetahui pengaruh terapi bermain puzzle terhadap tingkat kecemasan akibat hospitalisasi pada anak usia toddler di ruang Durian RSUD Kabupaten Klungkung, diperoleh nilai $p=0,000$ yang artinya nilai $p$ $<0,05$, sehingga ada pengaruh tingkat kecemasan anak usia toddler sesudah diberikan terapi bermain puzzle. Keadaan stres akan mengaktivasi amygdala pada sistem limbik, sistem ini akan menstimulasi pelepasan hormon corticotropic releasing hormone (CRH) dari Hipotalamus. Peningkatan $\mathrm{CRH}$ akan menstimulasi pelepasan adenocorticotropim hormone $(\mathrm{ACTH})$ kedalam darah. Peningkatan kadar ACTH akan menyebabkan peningkatan kortisol (sering dikenal dengan hormon stres) darah, karena ACTH merangsang kelenjar adrenal untuk menyekresikan kortisol (Alfiyanti, 2010). Peningkatan kortisol dalam darah juga akan mensupresi (menekan) immunoglobin A (igA) yang merupakan immunoglobulin utama dalam sekresi seromukosa untuk mejaga permukaan luar tubuh (Alfiyanti, 2010).

Terapi bermain puzzle dapat mengurangi kecemasanya, melatih memorinya, mengasah keterampilan motorik halus anak, dan melatih keterampilan sosial (Soebachman, 2012). Anak dapat melatih memorinya dalam bermai puzzle pada saat anak mencoba mengingat kembali potongan gambar, pola, atau kata-kata yang telah dicoba. Melatih memori pada anak, bermain puzzle juga dapat melatih motorik halusnya, saat bermain puzzle anak-anak diminta untuk memasang atau memindahkan potongan kecil atau besar dari gambar-gambar, melingkari huruf atau kata-kata, memutar kenop atau memasukkan potongan puzzle ke dalam lubang tertentu sesuai bentuknya. Aktivitas ini akan mengasah keterampilan motorik halus, yang sangat diperlukan untuk melakukan aktivitas sehari-hari (Soebachman, 2012)

\section{KESIMPULAN}

Implikasi

Penelitian ini menemukan terdapat pengaruh pemberian terapi bermain puzzle terhadap tingkat kecemasan akibat hospitalisasi pada anak usia toddler. Pemanfaatan terapi bermain puzzle secara berkelanjutan untuk mengurangi kecemasan dapat dilakukan sehingga mampu melatih motorik halus anak serta dapat meningkatkan daya ingat anak. Dengan demikian, anak usia 1-3 tahun dapat 
Gede Sukadana, dkk: Pengaruh Terapi Bermain Puzzle Terhadap Tingkat Kecemasan Akibat Hospitalisasi Pada Anak Usia Toddler

terdistraksi melalui pengalihan fokus melalui permainan yang mengasah kemampuan otak.

\section{Keterbatasan}

Pada pelaksanaan penelitian ini peneliti mengalami keterbatasan seperti masa penelitian yang menjadi lebih lama yang diakibatkan minimnya jumlah toddler yang mememuhi kriteria sampel. Selain itu, sebagian besar anak lebih nyaman dan merasa tidak cemas jika bersama ibu, hal ini dapat menimbulkan bias dalam pemberian intervensi.

\section{DAFTAR PUSTAKA}

Adriana, D. (2013). Tumbuh Kembang dan Terapi Bermain Pada Anak. Jakarta: Salemba Medika.

Aizah, S., \& Wati, S. E. (2014). Upaya Menurunkan Tingkat Stres Hospitalisasi Dengan Aktifitas Mewarnai Gambar pada Anak Usia 4-6 Tahun di Ruang Anggrek RSUD Gambiran Kediri. Journal EFEKTOR, 25(1), 6-10.

Alfiyanti, N. (2010). Upaya Meningkatkan Daya Pikir Anak melalui Permainan Edukatif. Universitas Muhammadiyah Surakarta.

Basford, L., \& Slevin, O. (2010). Teori dan Praktik Keperawatan: Pendekatan Integral Pada Asuhan Pasien. (A. Waluyo \& M. Ester, Eds.). Jakarta: EGC.

Dikes Kabupaten Klungkung. (2015). Profil Kesehatan Kabupaten Klungkung 2014. Semarapura.

Kementerian Kesehatan RI. (2010). Rencana Strategis Kementerian Kesehatan 2010-2014. Jakarta: Kementerian Kesehatan RI.

Nursalam. (2013). Metode Penelitian Ilmu Keperawatan. Jakarta: Salemba Medika.

Saputro, H., \& Fazrin, I. (2017). Anak Sakit Wajib Bermain di Rumah Sakit: Penerapan Terapi Bermain Anak Sakit; Proses, Manfaat dan Pelaksanaannya. (E. A. Yalestyarini, Ed.). Ponorogo: Forum Ilmiah Kesehatan (FORIKES).

Soebachman, A. (2012). Pemainan Asyik
Bikin Anak Pintar. Yogyakarta: In Azna Books.

Wahyuni, Suwani, A., \& Murtutik, L. (2013). Hubungan Frekuensi Hospitalisasi Anak Dengan Kemampuan Perkembangan Motorik Kasar Pada Anak Pre School Penderita Leukemia di RSUD Dr. Moewardi. Jurnal Ilmu Keperawatan Indonesia, 1(1), 40-50.

WHO. (2012). World Health Statistics. World Health Organization. Geneva.

Wong, D. L., Hockenberry-Eaton, M., Wilson, D., L.Winkelstein, M., \& Schwartz, P. (2008). Buku Ajar Keperawatan Pediatrik. Jakarta: EGC. 